\title{
Fire EFFECTS AND Fire HISTORY OF Mesa Verde National Park
}

\author{
LISA FLOYD-HANNA \\ SAN JUAN COLLEGE $\bullet$ FARMINGTON \\ BILL ROMME $\bullet$ FORT LEWIS COLLEGE \\ DURANGO
}

\section{- INTRODUCTION}

Mesa Verde consists of a series of mesas in a north to south trend. The mesa tops are narrow strips, cut by numerous canyons of varying depth. Mesa Verde sandstones, particularly the Cliff House Formation, form the canyon slopes. Long Mesa, an area of focus in this study, has an elevation $2180 \mathrm{~m}$ at the south to $2517 \mathrm{~m}$ at the north end. Long Canyon cuts down to an elevation of $2133 \mathrm{~m}$. The vegetation on Long Mesa is a mosaic of mature piñon-juniper woodlands and mountain shrub associations. Shrub associations range from Gambels oak, (Quercus gambelii), and serviceberry, (Amelancheir utahensis), to Black Sagebrush, Artemesia nova), and Bitterbrush, (Purshia tridentata).

Although there is a body of information concerned with the effect of fire on piñon-juniper woodlands, there are no adequate studies of the shrub-rich piñon-juniper ecosystem of Colorado. Succession following fire was documented by Erdman (1970) in Mesa Verde National Park. He reported that annuals dominate initially, then perennial grasses and forbs, followed by shrub invasion. The open shrub stage becomes a "thicket" approximately 100 years after the fire. The shrubs, he suggests, are outcompeted by piñon and juniper trees, which dominate by about 300 years.

Fire and its relationship to resource management in Mesa Verde Park has been outlined by Omi and Emrick (1980). Focus was given to succession (cover and frequency of grass and shrub elements) following the 1873, 1934, and 1972 fires, and models predict the possibilities of control over moderate and severe fires in various vegetation classes within the Park. The study was concerned primarily with the nature of fire behavior and various fire-related management tools for use by Resource Management personnel.

Our observations suggest that there may be considerable heterogeneity in early post-fire successional patterns across a range of habitat types and fire severity within Mesa Verde National Park. Of particular interest is the distinct lack of piñon and juniper seedlings and saplings in all shrub associations on the northwest end of the Mesa. Thus, we cannot predict a successional pattern leading to a piñon-juniper woodland, such as found on the southern end of the Mesa, for other areas of the Park. We have developed two tentative working models which provided the framework for the 1992 field season. The model of fire behavior and vegetation patterning of north-central Mesa Verde differs from that of south-central Mesa Verde in several critical respects. Differences in substrate, derived from Cliffhouse sandstones in the south and Menifee shales in the north, and geographic position relative to the wind patterns (upwind or downwind from potential ignitions), play critical roles in fire behavior and recovery. Our model also predicts a 
north-south variation in fire behavior that results from severity and frequency of previous fires, and the subsequent successional seres which result from the past fire experience. The effects of fire on small mammal and avian populations must also be considered, as piñon-juniper invasion is tied closely to disperser and predator activity (e.g. Ligon 1978). The masting reproductive cycle of piñon (Floyd and Richardson 1984) also affects potential regeneration within the fire cycle. Juniper reproduction also fluctuates from one year to the next. These and other factors are being considered by our research team as we search for predictions about fire responses in the Mesa Verde vegetation.

\section{SPECIFIC OBJECTIVES AND METHODS OF 1992 FIELD SEASON}

Objective 1. To continue measurements of fire severity parameters along gradients of habitat and fire intensity within the 1989 Long Mesa Burn.

Objective 2. To document third-year patterns of early post-fire succession in relation to gradients of habitat and fire intensity.

Three sampling grids were established in 1991 to include the range of severity and affected vegetation on Long Mesa, within Long Canyon, and on the North Escarpment of Mesa Verde National Park:

1. Long Mesa Southern Grid (Grid \#1): This grid consists of a square kilometer, sampled every 100 meters, or a total of 121 sampling points. It was chosen to represent the heterogeneity of vegetation within the Piñon-juniper woodland region of the Park which has resulted from the 1934 fires (Wickiup Canyon and Wildhorse Fires), the 1972 Rock Springs fire, the 1989 Long Mesa Fire, and possibly a fire that occurred about 1873 (Erdman, 1970). This sampling and grid also spans Long Mesa and Long Mesa Canyon. "Control points" consist of vegetation missed by the 1989 fire. Data were collected from May 18-June 4 and August 1-10, 1992. At each point we tallied all trees within a radius of $4 \mathrm{~m}$ and recorded the species, dbh, and condition of each (i.e. dead, injured, uninjured). The $\%$ cover of living plants, unburned litter, burned litter, bare mineral soil, and rock substrates were sampled within four
$0.25 \mathrm{~m}^{2}$ quadrats. Sampling within these plots was by means of a point-intercept sampling frame (Mueller-Dombois and Ellenburg 1974). The sampling frame was placed 4 times (at 1 or $3 \mathrm{~m}$ either side of sampling point) and the vegetation or substrate intersected by junctions on the grid were recorded. Alternating with the placement of the sample quadrat, we excavated a shallow hole with a hatchet and measured the depth of soil char. The dominant grasses and forbs were recorded, and the number or burned and unburned stems of shrubs and trees were counted. Rock spalling was noted as an indicator of fire intensity. Site characteristics were recorded. Data are now being stored on a Macintosh LC computer on JMP Version 2 Statistical Package (SAS Institute 1989). This program allows data to be directly transferred to SAS format. SAS is available at San Juan College if further analysis is required. Data analysis will be carried out during the winter, 1992.

2. Long Mesa Northern Grid (Grid \#2): The second grid was placed within the treeless, shrub-dominated community which extends over much of the northern sector of Mesa Verde Park. As the vegetation was fairly homogenous and the known fire history less complex than that of the Southern Grid the size was reduced to $1 \mathrm{~km}$ by $0.6 \mathrm{~km}$, and the number of sampling points to 66 . Data were collected as outlined above.

3. North Escarpment Grid (Grid \#3): The Long Mesa fire jumped over the North Escarpment, and ran in strips down toward the base of this steep slope. The terrain was very difficult to sample, so the grid placement and sampling structure was modified for safety of the personnel. Grid \#3 covers the DouglasFir shrub association which is found infrequently and typically on north-facing slopes, in the Park. The grid ran $0.5 \mathrm{~km}$ in length and $0.4 \mathrm{~km}$ in width, and sample points were placed every $50 \mathrm{~m}$. Data collection was identical to that described above.

Data collected in 1992 are not yet statistically analyzed, so it is premature to compare post fire succession in the two years of our study. One observation, however, cannot escape mention at this point. Our goal is to determine the successional sequence which occurs in a non-seeded, non-altered area after catastrophic fire. In the northern expanse of Long Mesa this is possible. We have, for example, documented a rapid return to perennial 
dominance through vigorous resprouting of native shrubs, especially oak and serviceberry. On the southern end of the Mesa however, temperatures were relatively high as the existing piñon and juniper trees burned, leaving bare soil and only patches of graminoid regeneration. In 1992, a year high in precipitation, the invasion by Carduus nutans and other noxious weeds has preempted the return of native vegetation. Rosettes are densely packed in clusters, and will provide next years flowering individuals. We believe that such invasion must be the focus of immediate study, and that possibly aggressive removal of noxious weeds will allow a return to the native successional pattern.

Objective 3. To use a new method of dating prehistoric fires, developed in 1991, to age shrub stands in the northwestern sections of Mesa Verde National Park. Stand ages will be the basis for a stand origin map representing fire history.

Figure 1 shows the location of sampling points placed in a grid across the northwestern regions of the Mesa. At each point, David Hanna and Lana Jo Chapin collected the largest, centermost stem from Quercus gambelii clones. At least 10 replicate clones were sampled at a point; greater than 10 were sampled if the site supported two or more size classes of oak stands. Each sample has been sanded and is being aged by Lisa Floyd-Hanna. Once aging is complete, the distribution of stand origin dates will be used to prepare a stand origin map of the sampled area of Mesa Verde National Park.

In the time frame allotted, we were able to sample from the western edge of the Park and continue across the shrublands to the Moccasin Mesa Road. Sampling was not accomplished in the shrubdominated areas on the extreme east sections of the Park, such as Whites, Big and Waters Mesas. These shrub rich areas should be sampled in future research efforts.

Because the southern end of Chapin and Wetherill Mesas are not shrub rich, other methods will have to be used to date the possible fire history of this piñon-juniper zone. We have surveyed areas in which fuel-reduction crews removed piñon and juniper trees, leaving stumps at ground level. These stumps can be sanded to yield visible annual ring patterns. The limited sampling accomplished in these cut areas indicates a viable method for dating trees in the shrub-poor zones. Interpretation of stand ages of piñon and junipers will be hampered by our lack of precise knowledge of the time between disturbance and woodland successional sere replacement. However, we will be better able to predict successional patterns in Mesa Verde when we complete our analysis of vegetation dynamics from the vegetation mapping project (Floyd-Hanna and Romme, 1991, 1992).

\section{$\checkmark \quad$ SUMMARY}

During the 1991-1992 field season at Mesa Verde National Park, the fire research team accomplished two goals. First, grid systems were established across the diversity of vegetation types burned in 1989 on Long Mesa and two years of sampling have been accomplished. We have become increasingly concerned at the level of noxious weed invasion on the southern end of Long Mesa where the relatively hot fire left bare mineral soil.

Our second objective was to test and utilize a method for dating past fires using the annual rings of shrubs which resprout after fires. This method is needed because fire scarring tree species are not available in the Park system. In 1991 we determined that this shrub-dating method will adequately predict stand origin dates. In 1992 we applied the method to a grid system over the northwestern section of the Mesa, and will use the Quercus gambelii cores to create a stand origin map, dating past fires in the Mesa Verde region.

\section{- LITERATURE CITED}

Bradley, A. F., N. V. Noste, and W. C. Fischer. 1992. Fire ecology of forests and woodlands in Utah. USDA For. Serv. Gen. Tech. Rept. INT-287.

Erdman, James A. 1970. Pinyon-juniper succession after natural fires on residual soils of Mesa Verde, Colorado. Brigham Young Univ. Series Vol XI (2). 


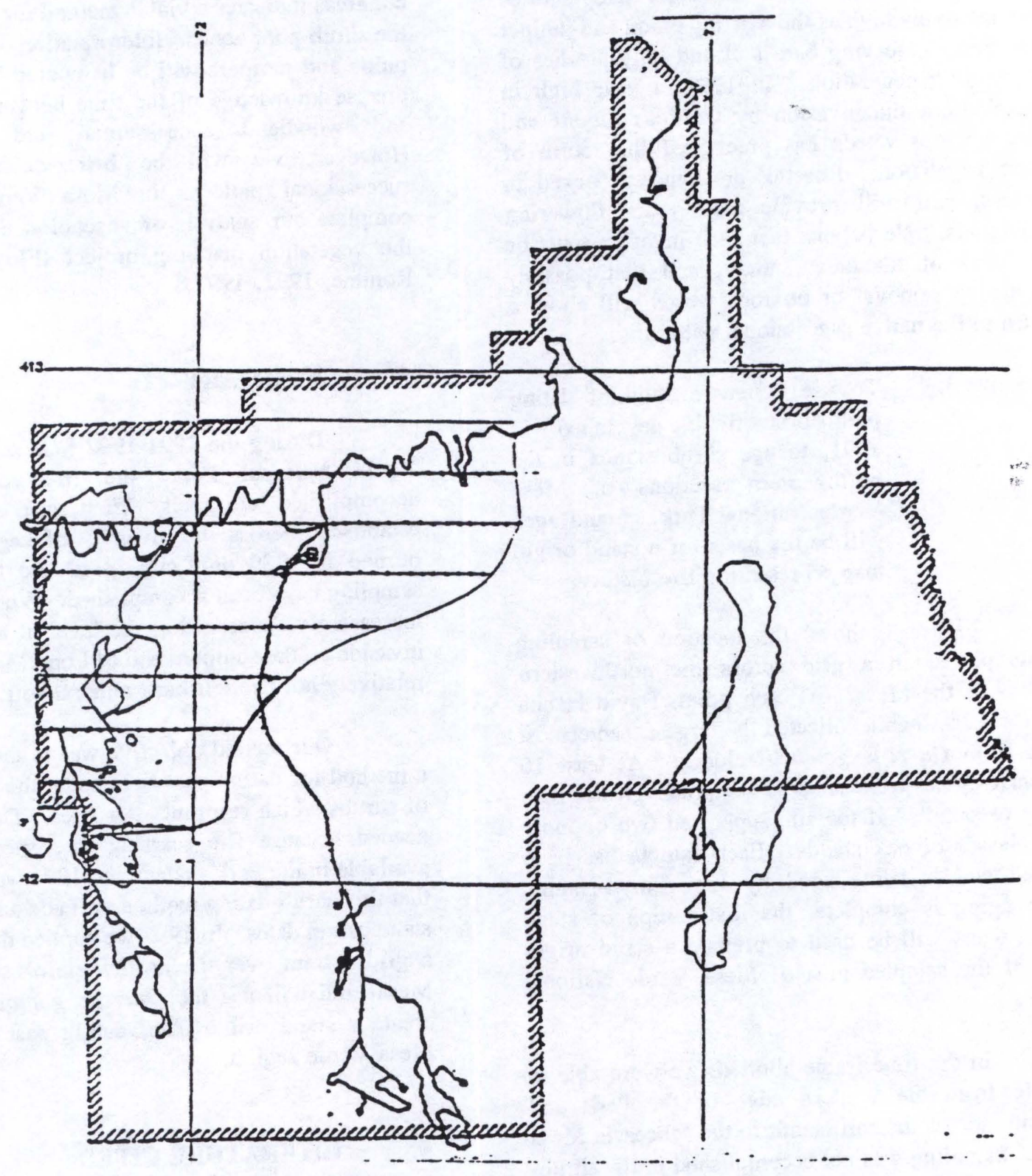

Figure 1. Location of stand origin sampling points. At each point indicated, 10 or more cross sections of the largest, central, Quercus gambeliistems were removed. Annual ring counts will be made to age the oak cross sections. 
Floyd, Mary E. and George P. Richardson. 1984. Entrained oscillations in piñon pines. Dynamica 10:39-41.

Floyd-Hanna, M. Lisa, William H. Romme and Kenneth Heil. 1991. Fire history and fire effects in Mesa Verde National Park Annual Report. Submitted to National Park Service, Rocky Mountain Region.

Floyd-Hanna, M. Lisa and William H. Romme. 1992. Fire history and fire effects in Mesa Verde National Park Semi-Annual Report. submitted to National Park Service, rocky Mountain Region.

Forcella, Frank. 1981. Ovulate cone production in pinyon: negative exponential relationship with late summer temperature. Ecology 62:488-491.

Keeley, John E. 1992. Recruitment of seedlings and vegetative sprouts in unburned chaparral.

Forcella, Frank. 1981. Ovulate cone production in pinon: negative exponential relationship with late summer temperature. Ecology 62:488491.
Ligon, J. David. 1978. Reproductive interdependence between piñon pines and piñon jays. Ecological Monographs 48:111126

Mueller-Dombois, D. and H. Ellenburg. 1974. Aims and methods in vegetation ecology. Wiley and Sons.

Omi, Philip, and Lance Emrick. 1980. Fire and resource management in Mesa Verde National Park. Contract CS-1200-9-B015 Final Report.

Romme, W. H. 1992. Fire and landscape diversity in subalpine forests of Yellowstone National Park. Ecological Monographs 52:199-221.

Turner, M. G., W. H. Romme, and R. H. Gardner. 1991. Influences of landscape heterogeneity on fire behavior and effects in the 1988 Yellowstone fires. MS submitted to Ecology. 